\title{
Conservation tillage vs. conventional tillage: long-term effects on yields in continental,
} sub-humid Central Europe, Hungary

\author{
Balázs Madarász ${ }^{\text {a,b,*, Katalin Juhos }}{ }^{\text {b }}$, Zsófia Ruszkiczay-Rüdiger ${ }^{\mathrm{c}}$, Szabolcs Benke ${ }^{\mathrm{a}}$, \\ Gergely Jakab ${ }^{\mathrm{a}}$, Zoltán Szalai ${ }^{\mathrm{a}}$, \\ ${ }^{a}$ Geographical Institute, Research Centre for Astronomy and Earth Sciences, Hungarian Academy of Sciences, \\ Budaörsi St. 45., 1112 Budapest, Hungary. \\ ${ }^{\mathrm{b}}$ Department of Soil Science and Water Management, Corvinus University of Budapest Faculty of Horticultural \\ Science, Villányi St. 29-43., 1118 Budapest, Hungary \\ ${ }^{\mathrm{c}}$ Institute for Geological and Geochemical Research, Research Centre for Astronomy and Earth Sciences, \\ Hungarian Academy of Sciences, Budaörsi St.45., 1112 Budapest, Hungary
}

\begin{abstract}
The present study reports novel data concerning Conservation Tillage (CT) in the continental sub-humid climate zone in Central Europe (Hungary), an area which has been mostly neglected in the course of previous CT studies. The results of a 10 year (2003-2013) comparative study of mouldboard ploughing tillage (PT) and CT (no inversion, using a reduced number of tillage operations and leaving min. 30\% crop residues on the soil surface) types are reported. Our extensive monitoring system has provided new and detailed information concerning technologies and yields both from the first, transitional period and, over the following years, of adapted technology. Our results suggest that tillage type was a more important factor in the question of yields than either the highly variable climate of the studied years, or the diverse slope conditions of the plots. During the first three years of technological changeover to CT (2003-2006) a decrease of $8.7 \%$ was measured, respective to PT. However, the next seven years (2007-2013) brought a $12.7 \%$ increase of CT yields. Our study revealed key factors in the initial reduction of crops during the technological change, and may accordingly serve as a guideline for the shortening or avoidance of decline in the transitional period.
\end{abstract}

Keywords: conservation agriculture, crop yield, winter wheat, maize, oil seed rape, weed control

\section{Introduction}

The main objective of Conservation Agriculture is to reverse the process of soil degradation and to conserve or improve available soil, water and biological resources. It is a combination of environmental conservation and enhanced and sustained agricultural production (FAO). The success of Conservation Agriculture technologies has been verified by their worldwide application over 125 million hectares (Friedrich et al. 2012). They are especially widespread in the Americas and Australia. Conservation Tillage (CT) is a set of practices that uses a reduced number of tillage operations with no inversion, leaving a minimum of $30 \%$ crop residues on the soil surface, which increases water infiltration and reduces erosion. Nevertheless, conservation tillage can be transition towards Conservation Agriculture (FAO).The dissemination of CT technologies had a relatively late start in Europe; nevertheless in 2010 CT tilled areas reached 22.7 million hectares (EU-28 + Iceland, Norway, Switzerland, Montenegro), which comprised 26\% of arable land (Eurostat 2010). The advantages of CT in erosion prevention and water management, and its effects on soil properties with a positive ecological and economic outcomes led to an increasing trend towards the spread of CT areas (Álvaro-Fuentes et al. 2007, Basch et al. 2008, Field et al. 2007, Holland 2004,Kassam et al. 2009, Lahmar 2010, Morris et al. 2010, Prasuhn 2012, Verch et al. 2009). Costs are reduced due to the omission of ploughing - a technique consuming a large amount of diesel oil -, by the employment of combined machines and by decreasing the number of passes. A decrease in the expenses even in the case of an unchanged yield results in extra profit, which could be important for the farmers during the technological shift. On the other hand, investigations were divided concerning yields. Several studies reported a minimum 5-10\% increase in yields straight away, from the first year (Bescansa et al. 2006, De Tourdonnet et al. 2007, Košutić et al. 2005, Su et al. 2007, Wang et al. 2012). Others draw attention to the hazards of long term conservation tillage: yields may drop due to

\footnotetext{
*Corresponding author.E-mail address: madarasz.balazs@csfk.mta.hu
} 
the increase of weeds and, occasionally, slug infection (El Titi 2003, Turley et al. 2003). Management decisions in appropriate to local conditions may be a key factor in decreasing yields as well (Koch and Stockfish 2006, Su et al. 2007). According to Soane et al. (2012) CT yields depend largely on soil quality, local geographical conditions and the weather of the studied year. Consequently, it is difficult to predict whether a farmer might expect increasing or decreasing yields after moving to CT. On the basis of 47 European studies, Van den Putte et al. (2010) concluded that conservation tillage reduces crop yields by $4.5 \%$.

The majority of the analyses were carried out in Northern and Western Europe, under cool and wet climate conditions (Anken et al. 2004, Armand et al. 2009, Koch and Stockfish 2006, Turley et al. 2003, Verch et al. 2009, Vullioud et al. 2006), and in the Mediterranean southern- southwestern part of the continent (Kassam et al. 2012, Melero et al. 2009, Moreno et al. 2006, Pagliai et al. 1995, Soane et al. 2012). On the other hand, there is a scarcity of data on continental, sub-humid East Central Europe. (Birkás et al. 2004, Grigoras et al. 2011, Madarász et al. 2011, Šíp et al. 2009, Videnović et al. 2011).

During the last decade, following the international trend, there has been a dynamic increase in the number of farmers shifting to CT technology in Hungary. We estimate that today some kind of CT is used on approximately $50 \%$ of cropland in Hungary. At least a quarter of these users, however, are not conscious CT users (i.e. they lack any proper training or experience). Accordingly, an increasing amount of scientific information is necessary to determine the relations between tillage practices and physical, chemical, and biological soil factors that affect plant and pest ecology (Gebhardt 1985).

At the beginning of our research, an experiment was set up in 2003, as part of the SOWAP (Soil and Surface Water Protection Using Conservation Tillage in Northern and Central Europe) project (2003-2006) (Kertész et al. 2007, Lane 2007) to study the conventional (mouldboard Ploughing Tillage; PT) and CT (with no inversion, using a reduced number of tillage operations and leaving min. $30 \%$ crop residues on the soil surface) in a comparative manner. Our main objective was to monitor the changes observed on both the PT and CT parts of the plot-pairs and observe evolution of the yields. Our study provides a direct comparison of PT and CT tillage types under controlled conditions. Statistical analysis was used to determine the effect of several variables on the yields of both tillage types, allowing an investigation into the reasons for the changing yields.

\section{Material and methods}

\subsection{The study area}

The study area is located in western Hungary, about $20 \mathrm{~km}$ southwest of Lake Balaton, near the village of Dióskál (Fig. 1A). The landscape is hilly (178-223 m a.s.l.) with slopes between 1 and $17 \%$. The parent material is loess, and the soils are Luvisols (Table 1).Soil profiles are eroded on the convex, upper part of the slopes, while thick soil sections are typical on the lower, concave slopes due to sedimentation. 


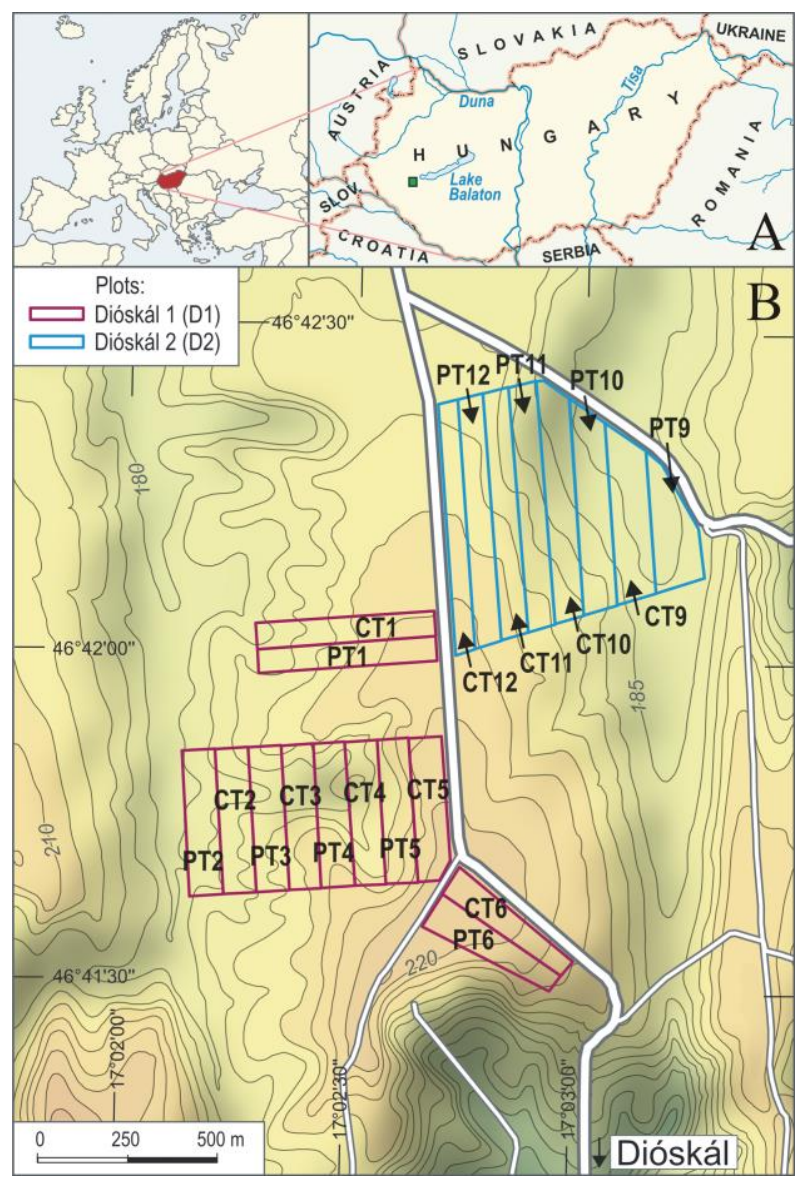

Fig. 1. A: Location of the study area (green rectangle). B: Setting of the experimental sites. CT 1-12: Conservation tillage plots; PT 1-12: Ploughing tillage plots

Table 1. Physical and chemical properties of the cultivated layer. Data result from a pit representative for the experimental field. The analysed samples were taken in spring, 2004. SOM: Soil Organic Matter; C/N: ratio between carbon and nitrogen; Clay $=<2 \mu \mathrm{m}$; Silt $=2-20 \mu \mathrm{m}$; Sand $=20-2000 \mu \mathrm{m}$

\begin{tabular}{ccccccccccc}
\hline Depth & $\mathrm{pH}$ & $\mathrm{pH}$ & $\mathrm{SOM}$ & $\mathrm{C} / \mathrm{N}$ & $\mathrm{CaCO}_{3}$ & $\begin{array}{c}\text { Bulk } \\
\text { density }\end{array}$ & Clay & Silt & Sand \\
\hline $\mathrm{cm}$ & $\mathrm{H}_{2} \mathrm{O}$ & $\mathrm{KCl}$ & $\%$ & $\%$ & $\%$ & $\mathrm{~g} \mathrm{~cm}^{-3}$ & $\%$ & $\%$ & $\%$ \\
\hline $0-15$ & 7.35 & 6.54 & 2.33 & 49.47 & 0.00 & 1.38 & 8.78 & 48.91 & 42.31 \\
$15-30$ & 7.29 & 6.56 & 1.82 & 43.45 & 0.00 & 1.56 & 9.48 & 52.14 & 38.38 \\
$30-45$ & 7.15 & 6.26 & 1.10 & 34.59 & 0.00 & 1.61 & 11.53 & 52.70 & 35.76 \\
\hline
\end{tabular}

Mean annual temperature between 2003 and 2013 was $11^{\circ} \mathrm{C}$, and the duration of the frostfree season varied between 180-200 days. Long-term mean annual precipitation is $700 \mathrm{~mm}$. However, it was only $619 \mathrm{~mm}$ in the studied time interval. In the growing season $430 \mathrm{~mm}$ precipitation can be expected (Hajósy et al. 1975) compared to the average of $396 \mathrm{~mm}$ measured for the studied period. (Table 2). 
Table 2. Climate data of the experimental site during the studied time interval (2003-2013). Data of the local automatic whether station (by CWi Technical Ltd).

\begin{tabular}{cccccccccccccc}
\hline & $\mathbf{2 0 0 3}$ & $\mathbf{2 0 0 4}$ & $\mathbf{2 0 0 5}$ & $\mathbf{2 0 0 6}$ & $\mathbf{2 0 0 7}$ & $\mathbf{2 0 0 8}$ & $\mathbf{2 0 0 9}$ & $\mathbf{2 0 1 0}$ & $\mathbf{2 0 1 1}$ & $\mathbf{2 0 1 2}$ & $\mathbf{2 0 1 3}$ & $\begin{array}{c}\boldsymbol{\varnothing 2 0 0 3}- \\
\mathbf{2 0 1 3}\end{array}$ \\
\hline $\begin{array}{c}\text { Mean air } \\
\text { temperature } \\
\quad \text { April-Sept. } \\
\quad\left({ }^{\circ}\right)\end{array}$ & 18.6 & 16.5 & 16.6 & 17.2 & 18.3 & 17.4 & 18.1 & 16.8 & 18.4 & 18.5 & 17.8 & 17.7 \\
$\begin{array}{c}\text { Mean annual air } \\
\text { temperature } \\
\quad\left({ }^{\circ} \text { C) }\right.\end{array}$ & 11.0 & 10.2 & 10.0 & 10.6 & 11.9 & 11.8 & 11.2 & 10.2 & 11.1 & 11.8 & 11.2 & 11.0 \\
$\begin{array}{c}\text { April-Sept. } \\
\text { precipitation } \\
\text { (mm) }\end{array}$ & 253 & 331 & 519 & 458 & 449 & 383 & 362 & 650 & 300 & 323 & 325 & 396 \\
$\begin{array}{c}\text { Annual } \\
\text { precipitation } \\
\text { (mm) }\end{array}$ & 423 & 607 & 670 & 589 & 701 & 543 & 641 & 870 & 438 & 491 & 841 & 619 \\
\hline
\end{tabular}

117

\subsection{Experimental design and tillage systems}

The study area (104.9 ha) was divided into 10 pairs of CT and PT plots of similar size ( 4 ha). Plots to the west of the road form the Dióskáll area (D1) and those to the east of the road are the Dióskál2 area (D2) (Fig. 1B). Plots were designed to include areas of the erosional and accumulational parts of the slopes for both tillage types, so that the degree of erosion of the Luvisoils would have no differential effect on the yields when comparing PT and CT.

The plot design was arranged in 2003 when the SOWAP project initiated, in congruence with the requirements of agro-ecological and ornithological studies (Field et al. 2007), and was confined to the land properties of the cooperating local farmers. Tillage occurred along contour lines at D2 and along the long axis of the plots at D1 due to the variable topography. Before the experiment, conventional tillage had been applied to the entire area.

Due to prior differences of crop-types on areas D1 and D2, we had to apply a somewhat different crop rotation to the two areas (Table 3).

Table 3. Crop rotation in the study area. Dióskál 1 (D1), Dióskál 2 (D2) experimental sites; W.: Winter; S.:

\begin{tabular}{cccccccccccc}
\hline \multicolumn{10}{c}{ Spring } \\
\hline D1 & W. wheat & Maize & W. wheat & Maize & W. wheat & Rape & W. wheat & Maize & S. barley & Rape \\
D2 & Maize & W. wheat & Maize & W. wheat & Rape & W. wheat & Rape & W. wheat & Maize & S. barley \\
\hline
\end{tabular}

This setting allowed a direct comparison of the two tillage types under the influence of similar external factors. An overview on the cultivation activities and equipment used in the study areas is provided in Table 4 .

Table 4. Cultivation activities and machinery used on the studied experimental sites, 2003-2013. KM drill: Kuhn Maxima Pneumatic spacing drill; H.: heavy; pl.: plough; Tsr harrow: Trailed spade rotary harrow; V.: Väderstad; $2 \times$ : two times 


\begin{tabular}{|c|c|c|c|}
\hline \multicolumn{2}{|c|}{ Dióskál 1 site } & \multicolumn{2}{|c|}{ Dióskál 2 site } \\
\hline Ploughing tillage & Conservation tillage & Ploughing tillage & Conservation tillage \\
\hline \multicolumn{2}{|c|}{ 2003/2004 Winter wheat } & \multicolumn{2}{|c|}{ 2003/2004 Maize } \\
\hline Ploughing (Reversible pl.) & Disking ( H. disc-harrow) $2 \times$ & Stubble disking (H. disc-harrow) & $\begin{array}{l}\text { Stubble disking, (H. disc- } \\
\text { harrow) }\end{array}$ \\
\hline $\begin{array}{l}\text { Stubble disking, (H. disc- } \\
\text { harrow) }\end{array}$ & Sowing (V. Rapid) & Ploughing (Reversible pl.) & Disking (H. disc-harrow) \\
\hline Seed-bed prep. (H. disc-harrow) & & Levelling & Seed-bed prep. (H. disc-harrow) \\
\hline Sowing (40 yr old mounted drill) & & $\begin{array}{l}\text { Seed-bed prep. (H. disc-harrow) } \\
\text { Sowing (John Deere) }\end{array}$ & Sowing (John Deere) \\
\hline \multicolumn{2}{|c|}{ 2004/2005 Maize } & \multicolumn{2}{|c|}{$2004 / 2005$ Winter wheat } \\
\hline $\begin{array}{l}\text { Stubble disking (H. disc-harrow) } \\
\text { Ploughing (Reversible pl.) } \\
\text { Levelling, (V. Rexius roller) } \\
\text { Sowing (John Deere) }\end{array}$ & $\begin{array}{l}\text { Green manure sowing, V. Rapid } \\
\text { Disking, Vadarstad Carrier } \\
\text { Sowing (John Deere) }\end{array}$ & $\begin{array}{l}\text { Ploughing (Reversible pl.) } \\
\text { Levelling (H. disc-harrow) } \\
\text { Seed-bed prep. (Tsr harrow) } \\
\text { Sowing (V. Rapid) }\end{array}$ & $\begin{array}{l}\text { Disking, Vadarstad Carrier 2x } \\
\text { Sowing (V. Rapid) }\end{array}$ \\
\hline \multicolumn{2}{|c|}{$2005 / 2006$ Winter weheat } & \multicolumn{2}{|c|}{ 2005/2006 Maize } \\
\hline $\begin{array}{l}\text { Ploughing (Reversible pl.) } \\
\text { Levelling (H. disc-harrow) } \\
\text { Sowing (V. Rapid) }\end{array}$ & $\begin{array}{l}\text { Disking (H. disc-harrow) } \\
\text { Sowing (V. Rapid) }\end{array}$ & $\begin{array}{l}\text { Liming } \\
\text { Stubble disking (H. disc-harrow) } \\
\text { Ploughing (Reversible pl.) } \\
\text { Levelling (V. Rexius roller) } \\
\text { Seed-bed prep. (Tsr harrow) } \\
\text { Sowing (Seed spacing drill) } \\
\end{array}$ & $\begin{array}{l}\text { Liming } \\
\text { Stubble disking (V. Carrier) } \\
\text { Disking (V. Carrier) 2x } \\
\text { Seed-bed prep. (Tsr harrow) } \\
\text { Sowing (Seed spacing drill) }\end{array}$ \\
\hline \multicolumn{2}{|c|}{ 2006/2007 Maize } & \multicolumn{2}{|c|}{$2006 / 2007$ Winter wheat } \\
\hline $\begin{array}{l}\text { Stubble disking (H. disc-harrow) } \\
\text { Levelling (V. Rexius roller) } \\
\text { Ploughing (Reversible pl.) } \\
\text { Levelling (V. Rexius roller) } \\
\text { Seed-bed prep. (Tsr harrow) } \\
\text { Sowing (KM drill) }\end{array}$ & $\begin{array}{l}\text { Stubble disking (H. disc-harrow) } \\
\text { Levelling (V. Rexius roller) } \\
\text { Disking, Vadarstad Carrier } 2 \times \\
\text { Sowing (KM drill) }\end{array}$ & $\begin{array}{l}\text { Disking (H. disc-harrow) } 2 \times \\
\text { Sowing (V. Rapid) }\end{array}$ & $\begin{array}{l}\text { Disking (V. Carrier) } \\
\text { Sowing (V. Rapid) }\end{array}$ \\
\hline \multicolumn{2}{|c|}{$2007 / 2008$ Winter wheat } & \multicolumn{2}{|c|}{ 2007/2008 Oil seed rape } \\
\hline $\begin{array}{l}\text { Ploughing (Reversible pl.) } \\
\text { Levelling (V. Rexius roller) } \\
\text { Seed-bed prep. (Tsr harrow) } \\
\text { Sowing (V. Rapid) }\end{array}$ & $\begin{array}{l}\text { Multicultivator (V. Top Down) } \\
\text { Seed-bed prep. (Tsr harrow) } \\
\text { Sowing (V. Rapid) }\end{array}$ & $\begin{array}{l}\text { Stubble disking (H. disc-harrow) } \\
\text { Medium deep subsoiling (Dondi) } \\
\text { Levelling (V. Rexius roller) } \\
\text { Seed-bed prep. (Tsr harrow) } \\
\text { Sowing (V. Rapid) }\end{array}$ & $\begin{array}{l}\text { Stubble disking (H. disc-harrow) } \\
\text { Multicultivator (V. Top Down) } \\
\text { Sowing (V. Rapid) }\end{array}$ \\
\hline \multicolumn{2}{|c|}{ 2008/2009 Oils seed rape } & \multicolumn{2}{|c|}{ 2008/2009 Winter wheat } \\
\hline $\begin{array}{l}\text { Stubble disking (V. Carrier ) } \\
\text { Ploughing (Reversible pl.) } \\
\text { Levelling (V. Rexius roller) } \\
\text { Seed-bed prep. (Tsr harrow) } \\
\text { Sowing (V. Rapid) }\end{array}$ & $\begin{array}{l}\text { Stubble disking (V. Carrier ) } \\
\text { H. duty cultivator (V. Cultus) } \\
\text { Sowing (V. Rapid) }\end{array}$ & $\begin{array}{l}\text { Stubble disking (H. disc-harrow) } \\
\text { Levelling (V. Rexius roller) } \\
\text { Disking (H. disc-harrow) } \\
\text { H. duty cultivator (V. Cultus) } \\
\text { Sowing (V. Rapid) }\end{array}$ & $\begin{array}{l}\text { Stubble disking (H. disc-harrow) } \\
\text { Levelling (V. Rexius roller) } \\
\text { Disking (H. disc-harrow) } \\
\text { H. duty cultivator (V. Cultus) } \\
\text { Sowing (V. Rapid) }\end{array}$ \\
\hline \multicolumn{2}{|c|}{ 2009/2010 Winter wheat } & \multicolumn{2}{|c|}{ 2009/2010 Oil seed rape } \\
\hline $\begin{array}{l}\text { Stubble disking (V. Carrier ) } \\
\text { Ploughing (Reversible pl.) } \\
\text { Levelling (V. Rexius roller) } \\
\text { Seed-bed prep. (Tsr harrow) } \\
\text { Sowing (V. Rapid) }\end{array}$ & $\begin{array}{l}\text { Stubble disking (V. Carrier ) } \\
\text { Disking (V. Carrier) } \\
\text { Seed-bed prep. (Tsr harrow) } \\
\text { Sowing (V. Rapid) }\end{array}$ & $\begin{array}{l}\text { Stubble disking (V. Carrier ) } \\
\text { Ploughing (Reversible pl.) } \\
\text { Levelling (V. Rexius roller) } \\
\text { Seed-bed prep. (Tsr harrow) } \\
\text { Sowing (V. Rapid) } \\
\end{array}$ & $\begin{array}{l}\text { Stubble disking (V. Carrier ) } \\
\text { H. duty cultivator (V. Cultus) } \\
\text { Seed-bed prep. (Tsr harrow) } \\
\text { Sowing (V. Rapid) }\end{array}$ \\
\hline \multicolumn{2}{|c|}{ 2010/2011 Maize } & \multicolumn{2}{|c|}{ 2010/2011 Winter wheat } \\
\hline $\begin{array}{l}\text { Stubble disking (V. Carrier ) } \\
\text { Ploughing (Reversible pl.) } \\
\text { Levelling (Tsr harrow) } \\
\text { Seed-bed prep. (Tsr harrow) } \\
\text { Sowing (KM drill) } \\
\text { Rolling (V. Rexius) }\end{array}$ & $\begin{array}{l}\text { Stubble disking (V. Carrier ) } \\
\text { H. duty cultivator (V. Cultus) } \\
\text { Seed-bed prep. (Tsr harrow) } \\
\text { Sowing (K M drill) } \\
\text { Rolling (V. Rexius) }\end{array}$ & $\begin{array}{l}\text { Stubble disking (H. disc-harrow) } \\
\text { Levelling (V. Rexius roller) } \\
\text { Disking (H. disc-harrow) } \\
\text { Seed-bed prep. (Tsr harrow) } \\
\text { Sowing (V. Rapid) }\end{array}$ & $\begin{array}{l}\text { Stubble disking (H. disc-harrow) } \\
\text { Levelling (V. Rexius roller) } \\
\text { Disking (H. disc-harrow) } \\
\text { Seed-bed prep. (Tsr harrow) } \\
\text { Sowing (V. Rapid) }\end{array}$ \\
\hline \multicolumn{2}{|c|}{ 2011/2012 Spring barley } & \multicolumn{2}{|c|}{ 2011/2012 Maize } \\
\hline $\begin{array}{l}\text { Stubble disking (V. Carrier ) } \\
\text { Ploughing (Reversible pl.) } \\
\text { Levelling (V. Rexius roller) } \\
\text { Seed-bed prep. (Tsr harrow) } \\
\text { Sowing (V. Rapid) } \\
\text { Rolling (V. Rexius) }\end{array}$ & $\begin{array}{l}\text { Stubble disking (V. Carrier ) } \\
\text { H. duty cultivator (V. Cultus) } \\
\text { Seed-bed prep. (Tsr harrow) } \\
\text { Sowing (V. Rapid) } \\
\text { Rolling (V. Rexius) }\end{array}$ & $\begin{array}{l}\text { Stubble disking (V. Carrier ) } \\
\text { Medium deep subsoiling (Dondi) } \\
\text { Levelling (V. Rexius roller) } \\
\text { Ploughing (Reversible pl.) } \\
\text { Levelling (V. Rexius roller) } \\
\text { Seed-bed prep. (Tsr harrow) } \\
\text { Sowing (K M drill) }\end{array}$ & $\begin{array}{l}\text { Stubble disking (V. Carrier ) } \\
\text { Medium deep subsoiling (Dondi) } \\
\text { Levelling (V. Rexius roller) } \\
\text { H. duty cultivator (V. Cultus) } \\
\text { Seed-bed prep. (Tsr harrow) } \\
\text { Sowing (K M drill) }\end{array}$ \\
\hline \multicolumn{2}{|c|}{ 2012/2013 Oil seed rape } & \multicolumn{2}{|c|}{ 2012/2013 Spring barley } \\
\hline $\begin{array}{l}\text { Stubble disking (V. Carrier ) } \\
\text { Medium deep subsoiling (Dondi) } \\
\text { Ploughing (Reversible pl.) } \\
\text { Levelling (V. Carrier) } \\
\text { Seed-bed prep. (V. Carrier) } \\
\text { Sowing (V. Rapid) } \\
\text { Rolling (V. Rexius) }\end{array}$ & $\begin{array}{l}\text { Stubble disking (V. Carrier ) } \\
\text { Medium deep subsoiling (Dondi) } \\
\text { Seed-bed prep. (V. Carrier) } \\
\text { Sowing (V. Rapid) } \\
\text { Rolling (V. Rexius) }\end{array}$ & $\begin{array}{l}\text { Stubble disking (V. Carrier ) } \\
\text { Ploughing (Reversible pl.) } \\
\text { Levelling (V. Rexius roller) } \\
\text { Seed-bed prep. (Tsr harrow) } \\
\text { Sowing (Mounted drill) }\end{array}$ & $\begin{array}{l}\text { Stubble disking (V. Carrier) } \\
\text { H. duty cultivator (V. Cultus) } \\
\text { Seed-bed prep. (Tsr harrow) } \\
\text { Sowing (Mounted drill) }\end{array}$ \\
\hline
\end{tabular}


Until the summer of 2007, when the soil was prepared for oil seed rape (D2), the PT plots were ploughed to a depth of 25-30 cm before each crop, in as much as this was allowed by the weather conditions. During the same period of time, on the CT plots soil was tilled using a non-inversion shallow tillage to a depth of 8-12 cm. Depth of CT tillage exceeded $12 \mathrm{~cm}$ only in case of heavy disc-harrowing (Table 4). In the autumn of 2007 the PT plots of the area D1 were ploughed, while on area D2 ploughing was replaced by medium-deep subsoiling (40-45 $\mathrm{cm})$. On the CT plots of both areas a multicultivator was used, meaning that the soil was prepared for sowing in one pass. In October 2008 the soil was very dry in area D2, hence it was not possible to plough. As a consequence, a heavy-duty cultivator was used on both PT and CT plots. In the extremely wet year 2010 (Table 2) on the D2 area heavy disc-harrowing occured on both cultivation types. In 2011 ploughing (PT plots) and cultivator tillage (CT plots) was carried out in area D1. On the other hand, in area D2 primary tillage started with medium deep subsoiling, which was followed by an autumn ploughing (PT plots) and a spring cultivator tillage (CT plots). In 2012, ploughing (PT plots) and cultivator tillage (CT plots) occurred on both areas, which was preceded by medium deep subsoiling in area D1. Fertilization, weed-control and harvesting were identical over the entire area.

The study was conducted in cooperation with the local farmers (on their land and not on a separate experimental area). Therefore, we started with the existing equipment of the landowners and had to hire the machines necessary for CT. Later the local equipment could be changed for more suitable machines, which had a stabilizing effect on the tillage.

\subsection{Statistical analysis}

The statistical analysis covers the period 2007-2013.The initial, transitional period of technological change (2003-2006) was excluded from the statistics. ANOVA was calculated for the comparison of mean yields of each tillage type. The statistical analysis was carried out using IBM SPSS Statistics 20 software.

Due to crop rotation, there is no yield data for each crop in each year on each plot. Yield data were standardized and compared in pairs using the Scheffe method among the post hoc tests. Considering the large standard deviation of yields in each year and the highly variable slope of the plots, the effect of the tillage types was studied in the light of these two factors (using two-way ANOVA) to reveal any relationship between the yield and the independent variables.

Independent variables were generated for the variance analysis as follows:

- tillage type: PT and CT

- year factor: years were clustered using Pálfai Drought Index (PAI; Pálfai 1988). This index has been developed specifically for climate conditions in Hungary, and expresses the importance of the distribution of precipitation during the growing season. The higher the index value, the greater the drought it expresses (PAI $<4$ means no drought, $\mathrm{PAI}>4$ means slight drought). PAI values for the study area fell between 2.9 and 5.1.

\section{Results}

The overview of the yields of the last 10 years shows that the turning point came after about the third year of the experiment (Fig. 2, Table 5). During the first three years, a significant loss of production occurred on the CT plots. The decrease was $3.8 \%$ on the D1 area, but on 
the D2 plots, a drop of $13.7 \%$ was measured. The largest negative values of wheat and maize crops were $-18.4 \%$ and $-18.9 \%$ in 2005 and 2006, respectively. After 2006 a spectacular change occurred. The following 7 years saw an average yield increase of $13.9 \%$ (D1) and 9.4\% (D2) compared to ploughing tillage.

202

203

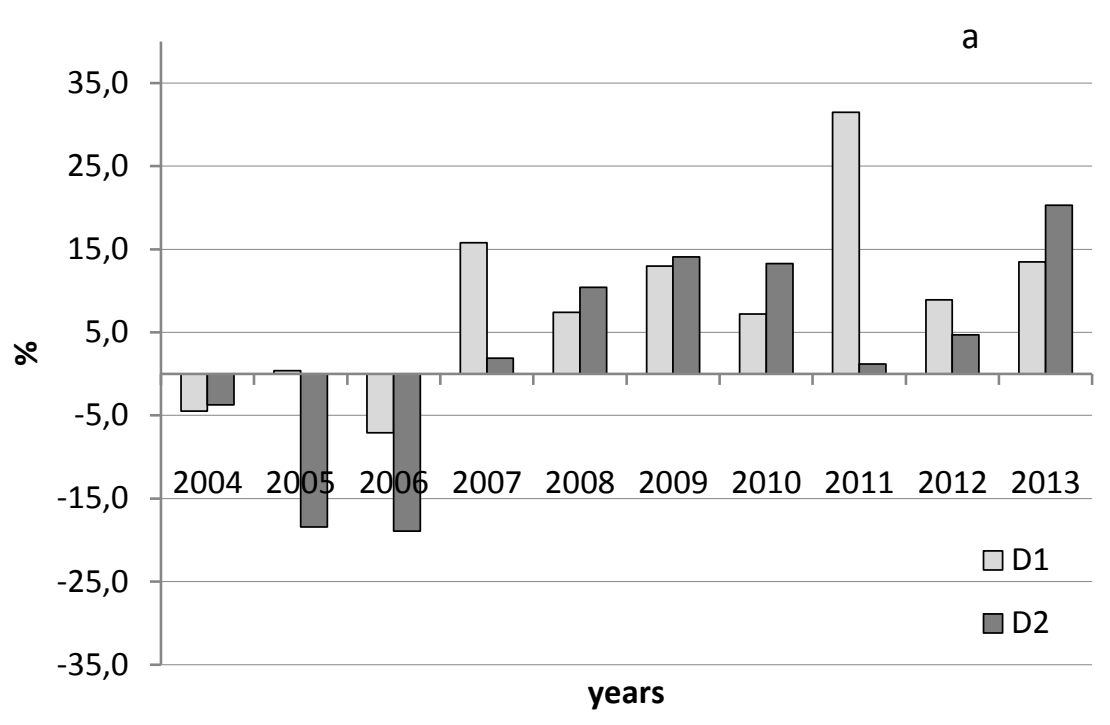

b

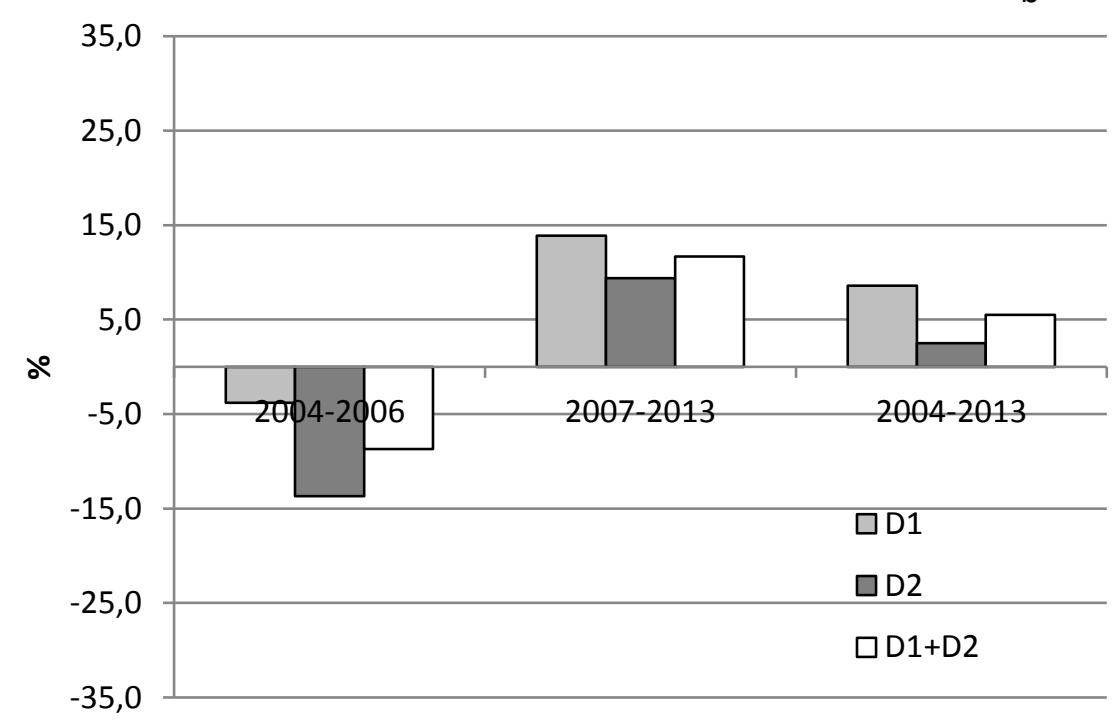

Fig. 2. Yields of the conservation tillage plots of the Dióskál 1 (D1) and Dióskál 2 (D2) areas expressed as the percentage of the yields of the ploughing tillage plots (a) by year, (b) for the average of the first (20042006), the second (2007-2013), and the entire experimental period 
Table 5. Yields of ploughing tillage (PT) and conservation tillage (CT) with standard deviation (SD) data of plots. Dióskál 1 (D1), Dióskál 2 (D2) study site

213

\begin{tabular}{|c|c|c|c|c|c|c|c|c|c|c|c|c|c|c|c|c|c|c|c|c|c|}
\hline & & \multicolumn{2}{|c|}{2004} & \multicolumn{2}{|c|}{2005} & \multicolumn{2}{|c|}{2006} & \multicolumn{2}{|c|}{2007} & \multicolumn{2}{|c|}{2008} & \multicolumn{2}{|c|}{2009} & \multicolumn{2}{|c|}{2010} & \multicolumn{2}{|c|}{2011} & \multicolumn{2}{|c|}{2012} & \multicolumn{2}{|c|}{2013} \\
\hline & & $\mathrm{Mg} \mathrm{ha}^{-1}$ & SD & $\mathrm{Mg} \mathrm{ha}^{-1}$ & $\mathrm{SD}$ & $\mathrm{Mg} \mathrm{ha}^{-1}$ & $\mathrm{SD}$ & $\mathrm{Mg} \mathrm{ha}^{-1}$ & SD & $\mathrm{Mg} \mathrm{ha}^{-1}$ & SD & $\mathrm{Mg} \mathrm{ha}^{-1}$ & SD & $\mathrm{Mg} \mathrm{ha}^{-1}$ & SD & $\mathrm{Mg} \mathrm{ha}^{-1}$ & $\mathrm{SD}$ & $\mathrm{Mg} \mathrm{ha}^{-1}$ & $\mathrm{SD}$ & $\mathrm{Mg} \mathrm{ha}^{-1}$ & $\mathrm{SD}$ \\
\hline \multirow{2}{*}{ D1 } & $\mathrm{PT}$ & 4.73 & 0.28 & 8.67 & 0.25 & 4.93 & 0.31 & 5.12 & 0.82 & 5.24 & 0.11 & 3.12 & 0.17 & 4.01 & 0.32 & 3.76 & 0.86 & 5.26 & 0.34 & 3.38 & 0.14 \\
\hline & CT & 4.51 & 0.49 & 8.71 & 0.35 & 4.58 & 0.40 & 5.92 & 0.46 & 5.62 & 0.39 & 3.53 & 0.19 & 4.30 & 0.51 & 4.95 & 0.45 & 5.73 & 0.20 & 3.83 & 0.11 \\
\hline \multirow{2}{*}{ D2 } & PT & 10.63 & 0.54 & 5.91 & 0.65 & 8.53 & 0.23 & 5.10 & 0.15 & 3.94 & 0.06 & 5.92 & 0.71 & 3.20 & 0.19 & 4.19 & 0.92 & 4.86 & 0.64 & 4.71 & 0.37 \\
\hline & CT & 10.24 & 0.54 & 4.82 & 0.38 & 6.92 & 0.74 & 5.20 & 0.17 & 4.35 & 0.18 & 6.76 & 0.41 & 3.63 & 0.10 & 4.24 & 0.67 & 5.09 & 0.92 & 5.66 & 0.27 \\
\hline
\end{tabular}




\subsection{Getting started - experiences of the 2003-2006 transitional period 3.1.1. Area D1 (2003-2006)}

In the autumn of the technological shift (2003), the sowing of the wheat was hindered by the large amount of precipitation (>200 $\mathrm{mm}$ in September and October). Yields in 2004 were somewhat smaller on the CT plots $(-4.5 \%)$ than on PT plots (Table 5), which might be attributed to the increase of weeds just before harvest time.

In 2004, after the harvest of the wheat, oil seed rape was sown using green manure on D1. This increased the costs of tillage significantly, although the disking of soil-protecting plants into the soil had a favourable effect. All these efforts resulted in a minimal surplus of the CT yield at the time of maize harvest $(0.4 \%)$. On the other hand, it has to be admitted that this minor surplus was mainly the result of significant game damage of the PT plots (PT2, PT6).

Several reasons stood in the background of the $7.1 \%$ deficit of the winter wheat yield of the CT areas during the 2005/2006 season with respect to the PT. The schedule was very tight due to the late harvest of maize at the end of October followed by the sowing of wheat in the beginning of November. The crop residues of the maize (NK Canada) could not be settled, and hence the stalks were drawn together by the Väderstad Carrier used for the tillage on CT plots. The first weed control after sowing was late and proved to be ineffective, which led to major problems on the CT plots later. Apera spica-venti (Common windgrass) appeared over large areas, especially on the CT3, 4, and 6 plots. This weed was the one that had already caused problems on the D2 plots in the previous year. Naturally, weed invasion was reflected by the low yields. The greatest difference between the two tillage types, $-0.8 \mathrm{Mg} \mathrm{ha}^{-1}(-16 \%)$ was found in plot-pair № 3 .

\subsubsection{Area D2 (2003-2006)}

In 2004, maize was sown in area D2. A minimal deficit of CT yield (3.7\%) compared to PT plots was measured, which was the result of the low productivity of the most weedy plots (CT10 and 12). On CT12, the largest amount of weeds appeared next to the public road. On CT10 shallow tillage allowed the survival of Equisetum arvense (Common horsetail), which was difficult to eliminate and led to a reduced yield.

In the autumn of 2004, maize was followed by winter wheat. The maize (NK Occitan, with a long growing season) produced a large mass of stalks under the favourable weather conditions during the vegetation season: on extensive areas the height of the plants reached 3 $\mathrm{m}$. This caused the first and major problem after the maize harvest: it was difficult to work the large amount of crop residue into the soil. Ploughing was problematic because the plough gathered the inadequately chopped stalks. Non-inversion tillage on the CT plots was even more demanding. The disc gathered the crop residues in front of the compacting roller and left them behind in large piles.

In spring/early summer of 2005, the large mass of crop residues left on the surface caused a strong fungal infection, which was the most severe on plot-pairs 9-10. At harvest, a clearly visible fusarium infection was observed on these plots. Another factor in the fusarium infection may have been the single fungicide treatment of the stock.

A further problem was weed infestation of the area. Weed control occurred belatedly, together with the previously mentioned fungicide treatment. As a consequence of the welldeveloped weeds on the CT plots, this late treatment proved to be ineffective. Apera spicaventi, and Cirsium arvense (Creeping thistle) caused problems over large areas, together with Equisetum arvense on the CT10 plot.

The loss of yield was more than $18 \%$ on the CT plots compared to the ploughed ones, with the largest gap of $35 \%$ on the CT-PT10 plot-pair.

During the third year (2006) maize was sown again. This was the fifth occasion on which shallow tillage took place on the CT plots (Carrier disc). Disking was late, and dicotyledonous plants with deeply-penetrating spiky roots capable of breaking the compacted disc pan layer were not involved in the crop rotation. Moreover, the primary tillage was not preceded by 
total weed control and the mechanical work of disking could not exercise its weed control effect because of the short time interval between the two passes.

Owing to the large amount of precipitation in May $(120 \mathrm{~mm})$, both the maize and the weeds emerged rapidly. On the CT plots, the weed inventory was exponentially higher with respect to the PT tillage with inverted soils. Rainy weather again led to a delay in pest control.

It was not possible to penetrate the spongy soil when weeds were still small, and spraying was ineffective because the rainy weather helped the weeds to survive. Weed pressure was significant on the CT10 (Equisetum arvense, Ambrosia artemisiifolia (Common Ragweed)) and CT12 plots (Polygonum aviculare (Common knotgrass), Ambrosia artemisiifolia). Besides, Echinochloa crus-galli (Cockspur grass) appeared in the deeper parts of the CT9.

The biggest loss of crops was registered on the CT10 and CT12 plots. Yields were 23-26\% lower than the $8.4 \mathrm{Mg} \mathrm{ha}^{-1}$ and $8.2 \mathrm{Mg} \mathrm{ha}^{-1}$ yields on the PT10 and PT12 plots, respectively.

\subsection{Adapted technology - success of the 2007-2013 years}

\subsubsection{The D1 area (2007-2013)}

In the fourth year of the experiment yields turned for the better. By now the conclusions could be drawn from the experiences of the first years: an adapted technology was developed to suit local conditions and adequate equipment was already available. Besides, this period of time was necessary for the rich soil fauna characteristic of CT tilled areas to appear (Madarász et al. 2011, Roger-Estradea et al. 2010).

In 2007 sowing of the maize occurred on time. Post-emergence weed control was adequate, which proved to be of major importance in this year of drought. During summer drought, the maize of CT plots remained green for a longer time than on the PT ones. In other words, CT tillage was able to retain moisture available for the plants in the soil. This excess humidity was measurable at harvest: the water content of the maize from the PT plots was $19.7 \%$, while CT maize contained $22.6 \%$ water. Standard deviation of the yields of CT plots was significantly smaller than that of the PT plots ( 0.46 and 0.82 , respectively). This suggests a higher confidence level of production on the CT plots in dry years.

In the autumn of 2007 the maize harvest was followed by a multicultivator tillage on CT plots. The tillage depth of $20-25 \mathrm{~cm}$ had a positive effect by loosening the disc pan developed during disking in the previous years and had a weed control effect as well. Weed invasion, which had hitherto been growing year by year, decreased dramatically. Consequently, the relatively late weed control was effective (31/03/2008), despite the fact that the plants were less developed than the year before. Finally, the crop of winter wheat was $7 \%$ greater on CT plots than on PT plots.

In 2008, a new plant was involved in the winter wheat-maize crop rotation: oil seed rape. The spiky roots of the dicotyledonous plants penetrated into deeper layers of the soil. This had a markedly positive effect by loosening the soil and improving its water management and aeration. As a result of well-performed primary tillage and favourable weather, the cropyields were $13 \%$ higher on the CT plots compared to the PT plots.

In the 2009-2010 season, the rape was followed by winter wheat. The yields were low in both tillage types ( $\mathrm{PT}=4.01 \mathrm{Mg} \mathrm{ha}^{-1} ; \mathrm{CT}=4.30 \mathrm{Mg} \mathrm{ha}^{-1}$ ), but $\mathrm{CT}$ plots showed a $7.2 \%$ surplus.

The extremely wet year 2010 was followed by 3 years of drought. In the spring of 2011, a heavy-duty cultivator was used for primary tillage on the CT, which was closed in one pass, resulting in a moisture storage effect manifested later.

The seeds emerged unevenly at both tillages because the upper soil was practically dry. In some cases the emergence of many plants was as late as June, after the first significant rainfall event. Weed conditions were also unfavourable, since the lack of rainfall made the first postemergence treatment ineffective in both tillage types. A second treatment occurred two months after sowing. Despite the two weed controls, crop yields remained low. However, soil conservation tillage paid off the financial resources invested in it (CT: $4.95 \mathrm{Mg} \mathrm{ha}^{-1}$ ), while ploughing tillage produced a significant loss (PT: $\left.3.76 \mathrm{Mg} \mathrm{ha}^{-1}\right)$. The difference between the tillage types in this year of drought reached $31.5 \%$. It is true, however, that PT6 was an area 
in which considerable game damage took place. On the other hand, if the pair of the most damaged plot (PT6-CT6) is removed from the comparison, the difference between the yields is still significant: $17.4 \%$ ( $\mathrm{PT}=4.13 \mathrm{Mg} \mathrm{ha}^{-1}$; $\left.\mathrm{CT}=4.85 \mathrm{Mg} \mathrm{ha}^{-1}\right)$.

In 2012, the dry weather continued, and for the first time during the program, spring barley was introduced. CT plants tolerated the dry and often hot weather better, which was again reflected by the yields with a level of nearly $0.5 \mathrm{Mg} \mathrm{ha}^{-1}(8.9 \%)$ excess production.

In 2012-2013, rape was planted again. As a consequence of the 2012 drought, soil preparation for the rape was problematic and sowing posed a great risk. By the time of sowing the quality of the soil surface was noticeably better on the CT plots. On the PT plots, in addition to larger clods, the ratio of dust fraction was considerably higher on the soil surface. Sowing was relatively delayed compared to the previous years and occurred in almost air-dry soil conditions. This was followed by rolling to smooth the surface, for effective weed control, soil moisture conservation and to ensure a uniform emergence. Development of the rape plants on CT areas was obviously better and even under the adverse weather conditions a yield surplus of $13.5 \%$ was achieved.

\subsubsection{Area D2 (2007-2013)}

The change on area D2 was less spectacular than on D1, since only a $2 \%$ yield surplus was achieved in 2007. The extreme drought was a problem during primary tillage. The weed cover of CT plots was significant in this year, as well. Nevertheless, the development of the plants was good, and this was assisted by the early weed control (in March). In this way crop loss could be avoided. The spread of Apera spica-venti, Equisetum arvense (CT10) and in smaller patches, of Cirsium arvense was significant.

In area D2 oil seed rape was introduced in the crop rotation in the autumn of 2007. New items integrated in the technology had a clear positive effect. Favourable weather conditions contributed to the positive changes, hence in 2008, peak yields of rape and in 2009 the highest ever yields of winter wheat were achieved.

In the autumn of 2007, on the PT areas only medium-deep subsoiling was carried out (instead of ploughing), which was followed by levelling and seed-bed preparation with a rotary harrow, leading to the further breaking-up of soil particles. In the CT areas multicultivator tillage was employed. As a consequence, the $115 \mathrm{~mm}$ precipitation falling after sowing in September plugged the macropores of the soil of the PT plots. In contrast, in the soil of the CT plots earthworm fauna proliferated owing to the CT tillage for several years (Bádonyi et al. 2008, Madarász et al. 2011). Due to the rainfall, earthworms crawled through the entire tilled layer up to the surface, providing plenty of macropores to accommodate the subsequent precipitation.

The year favoured the cultivation of rape and gave the highest yields of rape to date. The $4.35 \mathrm{Mg} \mathrm{ha}^{-1}$ yield in CT tillage exceeded by $0.4 \mathrm{Mg}(+10.4 \%)$ the average yield of the PT area, with very low standard deviation values.

In 2008/2009 winter wheat was produced. In the autumn of 2008, ploughing of the highly desiccated soil was not possible, hence preparation for sowing was the same everywhere, regardless the plot type (Table 4). In addition to the favourable weather conditions during the growing season, the good forecrop (rape), the autumn weed control, the top-dressing, the double fungicide treatment and the application of growth regulator and foliar-feed secured the high yields. Weed conditions were also favourable owing to the deeper tillage and to the early weed control. CT tillage exceeded PT tillage by $14.1 \%$.

In 2010, after rape in 2008 and winter wheat in 2009, rape was sown again, which cannot be considered a sensible choice. Its disadvantages soon manifested themselves. Pesticide treatment was already required in autumn, and yields decreased by almost $18 \%$ compared to the results of two years previously. Despite all of this, the CT plots again performed better in this extreme wet year and showed more than $13 \%$ yield surplus, with a surprisingly low standard deviation $(\mathrm{SD}=0.1)$. 
Sowing of the winter-wheat was hindered by the rainy weather (August: $154 \mathrm{~mm}$; September: $151 \mathrm{~mm}$ ). Along with the pest control treatments, weed control was late, but the fungicide treatments occurred on time. The low yields ( $\mathrm{PT}=4.19 \mathrm{Mg} \mathrm{ha}^{-1} ; \mathrm{CT}=4.24 \mathrm{Mg} \mathrm{ha}^{-1}$ ) of winter-wheat were the consequence of the dry weather prevailing since November 2010 and the unusually hot weather during the flowering period in 2011 (unfavourable for fertilization). 2011 was the driest year of the studied period $(438 \mathrm{~mm})$. CT plots reached a surplus of only $1.2 \%$ under these unfavourable conditions (with the ploughing being skipped on PT plots). In 2012, owing to good timing, weed control of the maize could be done in one pass. Unfortunately, the drought led to a very early harvest with low yields. Soil conservation tillage produced a surplus of $4.7 \%$ in comparison with the conventional tillage ( $\mathrm{PT}=4.86 \mathrm{Mg}$ $\mathrm{ha}^{-1} ; \mathrm{CT}=5.09 \mathrm{Mg} \mathrm{ha}^{-1}$ ).

In 2012-2013 spring barley was produced, encouraged by the positive cultivation experiences of the previous year in D1 and due to its role in crop rotation. Before spring barley, maize was produced in the area, the chopping and stubble disking of which was successful.

In spring of 2013, the PT plots were ploughed and multicultivator tillage was carried out on the CT plots. At harvest, $1 \mathrm{Mg}$ more crop was collected on CT plots $\left(\mathrm{P}=4.71 \mathrm{Mg} \mathrm{ha}^{-1}\right.$; $\mathrm{CT}=5.66 \mathrm{Mg} \mathrm{ha}^{-1}$ ) despite the fact that spring barley was laid on significant areas of the CT plots, which appeared at harvest as a loss. During cultivation, as a result of professional farming techniques, neither fungal nor insect damage occurred and weed conditions were favourable.

\section{Discussion}

\subsection{Statistical analysis}

Considering the yields of the first three years, a deficit of $8.7 \%$ was measured, while the next seven years brought a $12.7 \%$ surplus. Averaging the 10 years together this means an overall $7.9 \%$ higher yield in favour of CT tillage. Remarkable differences were found for each crop: winter wheat produced the smallest and the maize the largest yield increase during the 20072013 period (Table 6).

Table 6. Productivity difference of conservation tillage (CT) plots for each crop with respect to plough tilled plots for the first (2004-2006), the second (2007-2013), and the entire experimental period. W.: Winter; S.: Spring

\begin{tabular}{lccc}
\hline & $\begin{array}{c}2004-2006 \\
\text { Transitional period } \\
(\%)\end{array}$ & $\begin{array}{c}2007-2013 \\
\text { Adapted CT } \\
(\%)\end{array}$ & $\begin{array}{c}\text { 2004-2013 } \\
\text { Entire studied period } \\
(\%)\end{array}$ \\
\hline W. wheat & -10.0 & +6.4 & -0.4 \\
Maize & -7.4 & +17.3 & +5.0 \\
Rape & & +12.6 & +12.6 \\
S. barley & & +14.6 & +14.6 \\
\hline All & -8.7 & +12.7 & +7.9 \\
\hline
\end{tabular}

In view of the period between 2007-2013, it can be concluded that each of the four plants gave higher yields in case of soil conservation tillage (Fig. 3). Considering the standardized yields of all plants, there is a significant difference between the two cultivation methods $(\mathrm{P}<0.01)$. The difference is not significant for wheat and maize $(\mathrm{P}<0.05)$. In the case of rape and of spring barley the difference is significant $(\mathrm{P}<0.01)$ (Table 7$)$. 


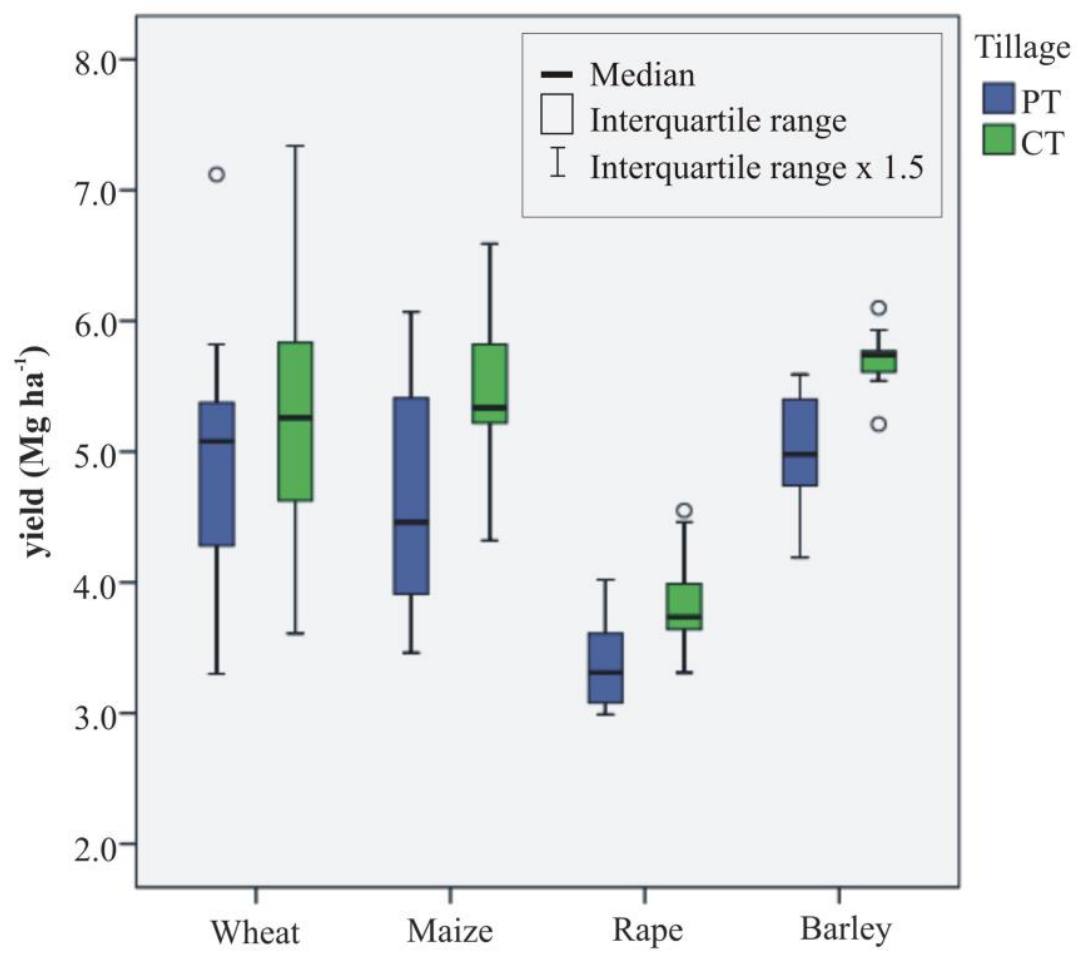

Fig. 3. Yields and distribution of yield data of ploughing tillage (PT) and conservation tillage (CT), 20072013

Table 7. Mean yields and standard deviation (SD) of each plant by tillage type (2007-2013) ** $\mathrm{P}<0.01$; Ploughing tillage (PT); Conservation tillage (CT).

\begin{tabular}{lccc}
\hline & $\mathrm{n}$ & $\begin{array}{c}\text { Mean yield } \\
\mathrm{Mg} \mathrm{ha}^{-1}\end{array}$ & $\mathrm{SD}$ \\
\hline W. wheat PT & 31 & 4.93 & 0.81 \\
W. wheat CT & 31 & 5.27 & 0.96 \\
Total & 62 & 5.10 & 0.90 \\
\hline Maize PT & 9 & 4.68 & 0.91 \\
Maize CT & 10 & 5.44 & 0.71 \\
Total & 19 & 5.08 & 0.87 \\
\hline Rape PT & 18 & $3.39^{* * *}$ & 0.35 \\
Rape CT & 18 & $3.82^{* *}$ & 0.35 \\
Total & 36 & 3.61 & 0.41 \\
\hline S. barley PT & 9 & $5.01^{* *}$ & 0.48 \\
S. barley CT & 9 & $5.70^{* *}$ & 0.25 \\
Total & 18 & 5.36 & 0.51 \\
\hline
\end{tabular}

During the studied period, extreme wet and dry years occurred. Therefore, ANOVA was also run in order to obtain a standardized result for all yields by year factor (PAI class). The results showed that the character (wet/drought) of the given year played a significant role $(\mathrm{P}<0.01)$. On the other hand, the PAI index generally shows a weak negative or positive correlation with the yields. Regarding each plant individually, the year-effect was considerable for all crops except the barley (Table 8, Fig. 4). 
Table 8. Change in yields $\left(\mathrm{Mg} \mathrm{ha}^{-1}\right)$ (both ploughing and conservation tillage) in relation to year factor (PAI). * $\mathrm{P}<0.05 ; * * \mathrm{P}<0.01$; values with the same letter within a row are not significantly different; Winter wheat (W. wheat); Spring barley (S. barley); a high value for the Pálfai Drought Index (PAI) indicates increasing aridity.

\begin{tabular}{lccccc}
\hline & \multicolumn{4}{c}{ PAI class } & \\
\cline { 2 - 5 } & 1. & 2. & 3. & 4. \\
& PAI $<3$ & PAI $=3-4$ & PAI=4-5 & PAI $>5$ & Mean \\
\hline W. wheat ** & $4.16 \mathrm{a}$ & $5.83 \mathrm{c}$ & $5.15 \mathrm{~b}$ & $4.94 \mathrm{~b}$ & 5.09 \\
Maize $*$ & & & $5.52 \mathrm{~b}$ & $4.58 \mathrm{a}$ & 5.05 \\
Rape $*$ & $3.42 \mathrm{a}$ & $3.66 \mathrm{~b}$ & & & 3.68 \\
S. barley & & $5.18 \mathrm{a}$ & & $5.49 \mathrm{a}$ & 5.34 \\
\hline
\end{tabular}



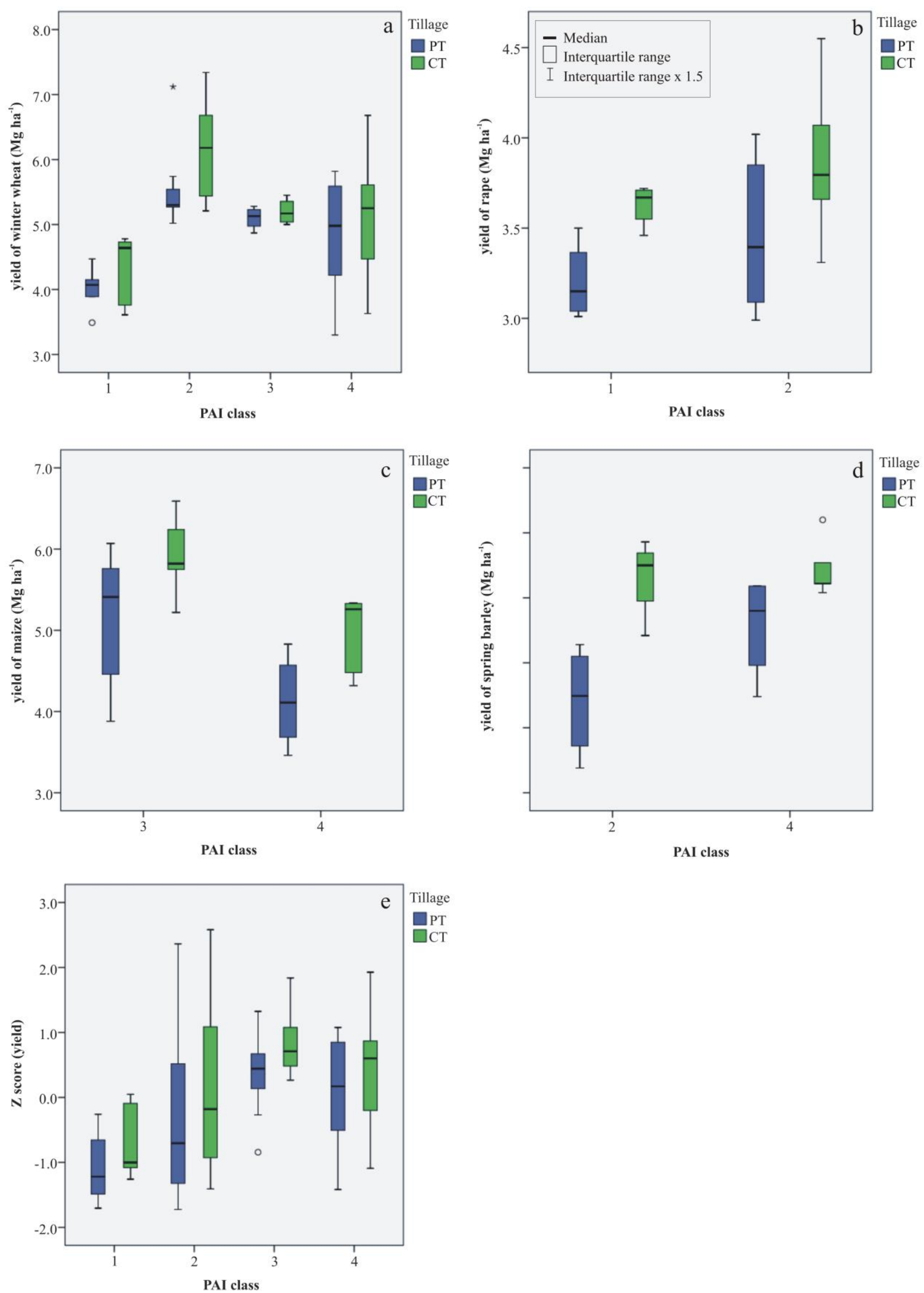

Fig. 4. Yields of winter wheat, maize, rape and spring barley during years of different aridity (year factor (Pálfai Drought Index, PAI; higher values indicate increasing aridity); z score: standardized yield data) 
Using the standardized yields for all plants and for each plant, a two-way ANOVA (tillage type, PAI) was run. However, the combined effect of the two factors could not be regarded as significant (Fig. 4). In other words, the observed yearly differences are not modified by the tillage type, and the effect of the tillage type is similar for each year.

The slope conditions had no significant effect on crop yields. A two-way ANOVA (tillage type, slope) was performed, again with the standardized yields. In a similar way to the previous ANOVA analysis he result did not prove the combined effect of these two factors, (Table 9, Fig. 5.), namely, the observed slope differences are not modified by the tillage type, and the effect of the tillage type is independent of the slope conditions. Accordingly, both the yields and the effects of tillage type are independent of topography at this study site.

Table 9. Percentage of different slope categories and the resulting plot class of the ploughing tilled (PT) and conservation tilled (CT) plots. D1.: Dióskál 1; D2.: Dióskál 2

\begin{tabular}{l|cccccc|cccc}
\hline & \multicolumn{6}{|c|}{ D1 } & \multicolumn{5}{c}{ D2 } \\
\hline Slope & PT1 & PT2 & PT3 & PT4 & PT5 & PT6 & PT9 & PT10 & PT11 & PT12 \\
\hline $0-5 \%$ & 52.4 & 28.3 & 25.0 & 40.9 & 71.4 & 65.4 & 87.5 & 42.6 & 23.5 & 64.9 \\
$5-12 \%$ & 47.6 & 71.7 & 75.0 & 47.3 & 28.6 & 34.6 & 12.5 & 57.4 & 74.2 & 35.1 \\
$12 \%<$ & 0.0 & 0.0 & 0.0 & 11.8 & 0.0 & 0.0 & 0.0 & 0.0 & 2.3 & 0.0 \\
Plot class & $\mathbf{4}$ & $\mathbf{5}$ & $\mathbf{5}$ & $\mathbf{4}$ & $\mathbf{3}$ & $\mathbf{3}$ & $\mathbf{1}$ & $\mathbf{4}$ & $\mathbf{5}$ & $\mathbf{3}$ \\
\hline
\end{tabular}

\begin{tabular}{l|cccccc|cccc}
\hline & \multicolumn{6}{|c|}{ D1 } & \multicolumn{5}{c}{ D2 } \\
\hline Slope & CT1 & CT2 & CT3 & CT4 & CT5 & CT6 & CT9 & CT10 & CT11 & CT12 \\
\hline $0-5 \%$ & 54.8 & 30.5 & 38.5 & 16.3 & 62.4 & 79.7 & 75.0 & 16.7 & 27.7 & 86.0 \\
$5-12 \%$ & 45.2 & 66.3 & 53.8 & 78.3 & 37.6 & 20.3 & 25.0 & 82.6 & 72.3 & 14.0 \\
$12 \%<$ & 0.0 & 3.2 & 7.7 & 5.4 & 0.0 & 0.0 & 0.0 & 0.7 & 0.0 & 0.0 \\
Plot class & $\mathbf{4}$ & $\mathbf{5}$ & $\mathbf{4}$ & $\mathbf{5}$ & $\mathbf{3}$ & $\mathbf{2}$ & $\mathbf{2}$ & $\mathbf{5}$ & $\mathbf{5}$ & $\mathbf{1}$ \\
\hline
\end{tabular}

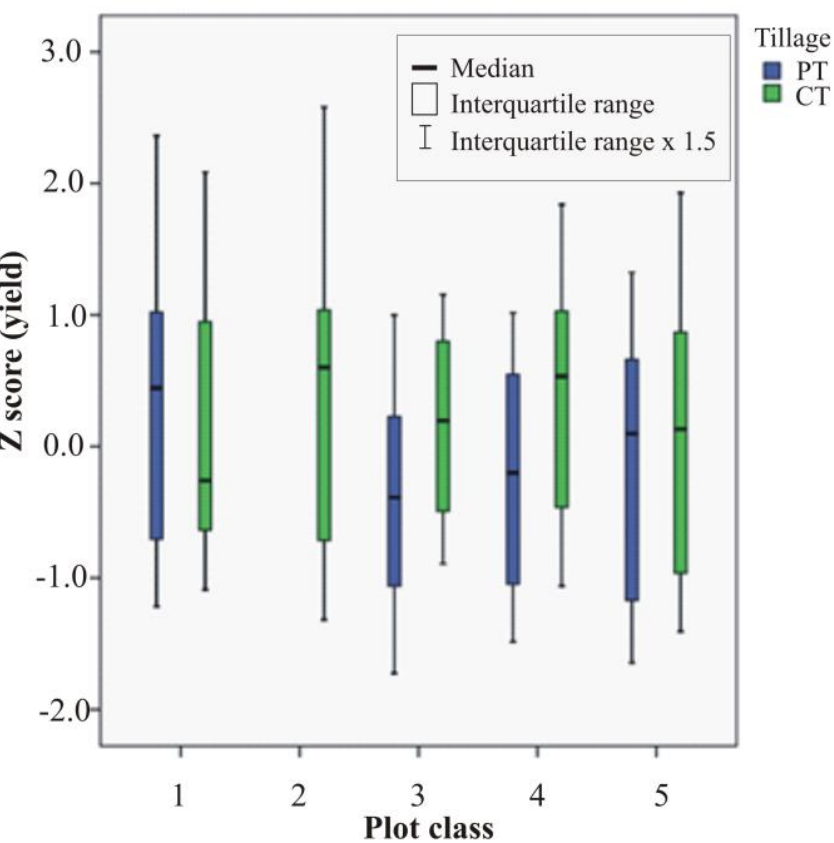

Fig. 5. Results of two-way ANOVA (tillage type and slope conditions) with standardized yields. Slope factor as in Table 9, higher values indicate steeper topography; z score: standardized yield data. 
In conclusion, the climate of the studied years was very variable and the plots of the study area are not homogeneous physically. These conditions, however, could not eliminate the effect of tillage type. In general, soil conservation tillage produced higher yields regardless of the aridity of the year, slope, and crop type.

472

473

474

475

476

477

478

479

480

481

482

483

484

485

486

487

488

489

490

491

492

493

494

495

496

497

498

499

500

501

502

503

504

505

506

507

508

509

510

511

512

513

514

515

516

517

518

519

520

\subsection{Experiences during the technological adjustment and advantages of the adapted CT compared to $P T$}

Most authors have emphasized the advantages of CT tillage (Holland 2004,Kassam et al. 2012, Melero et al. 2009, Prasuhn 2012), but problems arising during the first years after the technological change over and difficulties related to the adjustment to CT technology were not addressed sufficiently. We consider that the sharing of experiences concerning the technological adjustment may be helpful in shortening the period of adjustment and reaching the desired level of efficiency sooner at other locations.

In our study, a significant $7.8 \%$ yield loss was measured in the first 3 years, when several factors, like insufficient knowledge of the new technology, lack of expertise and the absence of adequate machines impeded the technological shift. Besides, due to the shallow tillage, more attention had to be paid to weed invasions, as examined by Koskinen and McWhorter (1986) as long ago as the 1980s. Our study supports that accurate, relevant and timely weed control is necessary in CT tillage, otherwise weeds may cause a considerable decrease of the yield. In our study area, the application of the multicultivator, as suggested by Batesa (2012), proved to be a successful means of weed control, as against the opinion expressed by Price and Kelton (2011), who suggested weed control based mostly on the application of chemicals. The method employed in the present study prevented the use of excess pesticides and thus reduced environmental loading.

Another important source of the initial decline was fungal infection caused by poorly chopped stalks and the large mass of crop residues left on the surface. During the period 2007-2013, our experiment demonstrated that this problem can be avoided by using adapted technology and adequate machinery. The proper chopping of stalk residues is a key element in improving conservation tillage.

A positive change was the integration of oil seed rape into the monotonous wheat-maize crop rotation in the autumn of 2007 and 2008. Statistically, during this 7-year period the year of production had the most significant effect on the yields, with no detectable correlation with aridity. The type of tillage is significant in general, but varies from plant to plant. In the case of wheat and maize, it had no significance, but in the case of rape and barley the connection could be demonstrated statistically. The effect of the tillage method, when evaluated together with the year-factor (describing the aridity of each year) and with the slope effect, suggests that soil conservation tillage provided higher yields independently of the year, plot and plant.

\section{Conclusions}

The present study demonstrates the most important advantages of CT under sub-humid continental climate conditions, and provides experiences of the initial period of reduced yields during the adjustment to the new technology. European studies mostly focus on the environmental benefits (in terms of soil and water management) and lower costs of CT tillage. Our study shows that the technological change may not be as smooth as expected on the basis of the above studies, and this may result in a considerable decrease in yields. The study also demonstrates that adaptation of the technology to local conditions is essential. Accordingly, we suggest that local studies are a prerequisite if farmers and decision makers are to be provided with appropriate information on the outcomes of a planned change from PT to CT tillage.

The experiences of the 10 years of monitoring the yields on twin PT and CT areas will provide guidelines to regional farmers and agricultural managers to implement CT technology while maintaining high yields. Our technology may be adapted by farmers in sub-humid continental climates where certain factors of production (e.g. slope, precipitation, weeds) are 
similar to those observed at our experimental site, and may help others to work out their adaptation methodology in other locations with somewhat different environmental conditions.

\section{Acknowledgements}

The research work was supported by the EU LIFE, Syngenta (LIFE03 ENV/UK/000617), Syngenta Hungary Ltd. and the Hungarian Scientific Research Fund (OTKA No. 104899, 100929). The authors express gratitude to Dr. B. Csepinszky for his field work, I. Plótár and his family for their agricultural works on the study site and Väderstad for the machinery. The authors also thank Prof. Á. Kertész for the remarks and N. Agárdi for his technical assistance that helped improve the quality of this project.

\section{References}

Álvaro-Fuentes, J., Cantero-Martınez, C., López, M.V., Arrúe, J.L., 2007. Soil carbon dioxide fluxes following tillage in semiarid Mediterranean agroecosystems. Soil Till. Res., 96, 331-341.

Anken, T., Weisskopf, P., Zihlmann, U., Forrer, H., Jansa, J., Perhacova, K., 2004. Long-term tillage system effects under moist cool conditions in Switzerland. Soil Till. Res., 78. 171-183.

Armand, R., Bockstaller, C., Auzet, A.-V., Van Dijk, P., 2009. Runoff generation related to intra-field soil surface characteristics variability application to conservation tillage context. Soil Till. Res., 102, $27-37$.

Basch, G., Geraghty, J., Stret, B., Sturny, W.G., 2008. No-tillage in Europe-state of the art: constraints and perspective. In: Goddard, T., Zoebisch, M.A., Gan, Y.T., Ellis, W., Watson, A., Sombatpanit, S., eds. NoTill Farming Systems. Bangkok:World Association of Soil and Water Conservation, 159-168.

Batesa, R.T., Gallagher, R.S., Curranb, W.S., Harperc, J.K., 2012. Integrating Mechanical and Reduced Chemical Weed Control in Conservation Tillage Corn. Agronomy Journal,104, 507-517.

Bádonyi , K., Hegyi, G., Benke, S., Madarász, B., Kertész, Á., 2008. Comparative agro-ecological study of tillage. Tájökológiai Lapok, 6, 145-163.

Bescansa, P., Imaz, M.J., Virto, I., Enrique, A., Hoogmoed, W.B., 2006. Soil water retention as affected by tillage and residue management in semiarid Spain. Soil Till. Res., 87, 19-27.

Birkás, M., Jolánkai, M., Gyuricza, C., Percze, A. 2004. Tillage effects on compaction, earthworms and other soil quality indicators in Hungary. Soil Till. Res., 78, 185-196.

De Tourdonnet, S., Nozi'eres, A., Barz, P., Chenu, C., Düring, R.A., Frielinghaus, M., Kölli, R., Kubat, J., Magid, J., Medvedev, V., Michels, A., Müller, L., Netland, J., Nielsen, N.E., Nieves Mortensen, C., Picard, D., Quillet, J.C., Saulas, P., Tessier,D., Thinggaard, K., Vandeputte, E., 2007. Comprehensive inventory and assessment of existing knowledge on sustainable agriculture in the European platform of KASSA. In: Lahmar, R., Arrue, J.L., Denardin, J.E., Gupta, R.K., Ribeiro, M.F.F., de Tourdonnet, S. eds. Knowledge Assessment and Sharing on Sustainable Agriculture. Montpellier:CIRAD, p. 54 (CD-Rom).

El Titi, A., 2003. Implications of soil tillage for weed communities. In: El Titi, A. ed. Soil Tillage in Agroecosystems. Boca Raton, USA:CRC Press, 147-185.

Eurostat, 2010. http://epp.eurostat.ec.europa.eu/portal/page/portal/eurostat/home (10/06/2014)

FAO 2015. http://www.fao.org/ag/ca/1a.html

Field, R. H., Benke, Sz., Bádonyi, K., Bragbury, R. B. 2007. Influence of conservation tillage on bird use of winter arable fields in Hungary. Agriculture. Ecosystems and Environment, 120, 399-404.

Friedrich, T., Derpsch, R., Kassam, A., 2012. Overview of the Global Spread of Conservation Agriculture. http://factsreports.revues.org/1941 (10/06/2014)

Gebhardt, M.R., Daniel, T.C., Schweizer, E.E., Allmaras, R.R., 1985. Conservation Tillage. Science,230, 625630 .

Grigoras, M.A., Popescu, A., Pamfil, D., Has, I., Cota, L.C., 2011. Effect of conservation agriculture on maize yield in the Transilvanian Plain, Romania. World Academy of Science, Engineering and Technology, Int. J. of Agricultural, 5, 4-9.

Hajósy, F., Kakas, J., Kéri, M., 1975. A csapadék havi és évi összegei Magyarországon - A mérések kezdetétől 1970-ig. Budapest: Országos Meteorológiai Szolgálat.

Holland, J.M., 2004. The environmental consequences of adopting conservation tillage in Europe: reviewing the evidence. Agriculture, Ecosystems \& Environment, 103, 1-25.

Kassam, A., Friedrich, T., Shaxson, F., Pretty, J., 2009. The spread of Conservation Agriculture: justification, sustainability and uptake. Int. J. of Agricultural Sustainability,7, 292-320.

Kassam, A., Friedrich, T., Derpsch, R., Lahmar, R., Mrabet, R., Basch, G., González-Sánchez, E.J., Serraj, R., 2012. Conservation agriculture in the dry Mediterranean climate. Field Crops Res., 132, 7-17.

Kertész, Á., Bádonyi, K., Madarász, B., Csepinszky, B. 2007. Environmental aspects of Conventional and Conservation tillage. In: Goddard, T., Zoebisch, M., Gan, Y., Ellis, W., Watson, A., Sombatpanit, S. eds. No-till farming systems. Bangkok:World Association of Soil and Water Conservation, 313-329. 
Koch, H.J. and Stockfisch, N., 2006. Loss of soil organic matter upon ploughing under a loess soil after several years of conservation tillage. Soil Till. Res., 86, 73-83.

Koskinen, W.C. and McWhorter, C.G., 1986. Weed control in conservation tillage. J. of Soil and Water Conservation, 41, 365-370.

Kšutić, S., Filipović, D., Gospodarić, Z., Husnjak, S., Kovačev, I., Čopec, K., 2005. Effects of different soil tillage systems on yield of maize, winter wheat and soybean on albic luvisol in North-West Slavonia. J. of Central European Agriculture, 6. 241-248.

Lahmar, R., 2010. Adoption of conservation agriculture in Europe: Lessons of the KASSA project. Land Use Policy, 27, 4-10.

Lane, M., (ed.) 2007. Conservation agriculture in Europe: An approach to sustainable crop production by protecting soil and water? Bracknell: SOWAP, Jealott's Hill International Research Centre.

Madarász, B., Bádonyi, K., Csepinszky, B., Mika, J., Kertész, Á., 2011. Conservation tillage for rational water management and soil conservation. Hungarian Geographical Bulletin, 60, 117-133.

Melero, S., López-Garrido, R., Madejón, E., Murillo, J.M., Vanderlinden, K., Ordóñez, R., Moreno, F. 2009. Long-term effects of conservation tillage on organic fractions in two soils in southwest of Spain. Agriculture, Ecosystems and Environment, 133, 68-74.

Moreno, F., Murillo, J.M., Pelegrín, F., Girón, I.F., 2006. Long-term impact of conservation tillage on stratification ratio of soil organic carbon and loss of total and active $\mathrm{CaCO}_{3}$. Soil Till. Res., 85, 86-93.

Morris, N.L., Miller, P.C.H., Orson, J.H, Froud-Williams R.J., 2010. The adoption of non-inversion tillage systems in the United Kingdom and the agronomic impact on soil, crops and the environment-A review. Soil Till. Res., 108, 1-15.

Pagliai, M., Raglione, M., Panini, T., Maletta, M., La Marca, M., 1995. The structure of two alluvial soils in Italy after 10 years of conventional and minimum tillage. Soil Till. Res., 34, 209-223.

Pálfai, I., 1988. Az aszály mértékének meghatározása. Tudomány és Mezőgazdaság, 26, 14-17.

Prasuhn, V., 2012. On-farm effects of tillage and crops on soil erosion measured over 10 years in Switzerland. Soil Till. Res., 120, 137-146.

Price, A. and Kelton, J., 2011.Weed Control in Conservation Agriculture. In: Soloneski, S. and Larramendy, M.L. eds. Herbicides, Theory and Applications, InTech, http://www.intechopen.com/books/herbicidestheory-and-applications/weed-control-in-conservation-agriculture

Roger-Estradea, J., Angerb, C., Bertrandb, M., Richardc, G., 2010. Tillage and soil ecology: Partners for sustainable agriculture. Soil Till. Res., 111, 33-40.

Šíp, V., Růžek, P., Chrpová, J., Vavera, R., Kusá, H., 2009. The effect of tillage practice, input level and environment on the grain yield of winter wheat in the Czech Republic. Field Crops Res., 113, 131-137.

Soane, B.D., Ball, B.C., Arvidsson, J., Basch, G., Moreno, F., Roger-Estrade, J., 2012. No-till in northern, western and south-western Europe: A review of problems and opportunities for crop production and the environment. Soil Till. Res., 118, 66-87.

Su, Z., Zhang, J., Wu, W., Cai, D., Lv, J., Jiang, G., Huang, J., Gao, J., Hartmann, R., Gabriels, D., 2007. Effects of conservation tillage practices on winter wheat water-use efficiency and crop yield on the Loess Plateau, China. Agricultural Water Management, 87, 307-314

Turley, D.B., Phillips, M.C., Johnson, P., Jones, A.E., Chambers, B.J., 2003. Long-term straw management effects on yield of sequential wheat (Triticum aestivum L.) crops in clay and silty clay loam soils in England. Soil Till. Res., 71, 59-69.

Van den Putte, A., Govers, G., Diels, J., Gillijns, K., Demuzere, M., 2010. Assessing the effect of soil tillage on crop growth: a meta-regression analysis on European crop yields under conservation agriculture. Eur. J. Agron., 22, 231-241.

Verch, G., Kächele, H., Höltl, K., Richter, C., Fuchs, C., 2009. Comparing the profitability of tillage methods in Northeast Germany-A field trial from 2002 to 2005. Soil Till. Res., 104, 16-21.

Videnović, Ž., Simić, M., Srdić, J., Dumanović, Z. Long term effects of different soil tillage systems on maize (Zea mays L.) yields. Plant Soil Environ., 57, 186-192.

Vullioud, P., Delabays, N., Frei, P., Mercier, E., 2006. Results of a 35-year ploughless tillage experiment at Changins 1970-2004. Part II: Physical and chemical soil properties. Revue Suisse d' Agriculture ,38, 1-16.

Wang, X., Wu, H., Dai, K., Zhang, D., Feng, Z., Zhao, Q., Wu, X., Jin, K., Cai, D., Oenema, O., Hoogmoed, W.B., 2012. Tillage and crop residue effects on rainfed wheat and maize production in northern China. Field Crops Res., 132, 106-116. 